\title{
Protection of plasmid DNA by a Ginkgo biloba extract from the effects of stannous chloride and the action on the labeling of blood elements with technetium-99m
}

S.R.F. Moreno $0^{1,2}$ R.S. Freitas ${ }^{2}$, E.K. Rocha ${ }^{2,3}$, G.L. Lima-Filho ${ }^{2}$ and M. Bernardo-Filho ${ }^{2,4}$
1Departamento de Patologia, Universidade Federal Fluminense, Niterói, RJ, Brasil Departamentos de ${ }^{2}$ Biofísica e Biometria and ${ }^{3}$ Biologia Celular e Genética, Universidade do Estado do Rio de Janeiro, Rio de Janeiro, RJ, Brasil

${ }^{4}$ Coordenadoria de Pesquisa, Instituto Nacional do Câncer, Rio de Janeiro, RJ, Brasil

\section{Correspondence \\ M. Bernardo-Filho \\ Laboratório de Radiofarmácia \\ Experimental \\ Departamento de Biofísica e Biometria \\ Instituto de Biologia, UERJ \\ Av. 28 de Setembro, 87 \\ 20551-030 Rio de Janeiro, RJ \\ Brasil \\ Fax: +55-21-2254-3532 \\ E-mail: bernardo@uerj.bror \\ srfmoreno@hotmail.com \\ Presented at the XVIII Annual Meeting of the Federação de Sociedades de Biologia Experimental, Curitiba, PR, Brazil, August 27-30, 2003. \\ Research supported by FAPERJ, CNPq, UERJ, UFF and CAPES}

Received April 10, 2003

Accepted November 10, 2003

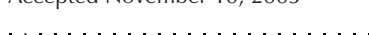

\begin{abstract}
Ginkgo biloba extract (EGb) is a phytotherapeutic agent used for the treatment of ischemic and neurological disorders. Because the action of this important extract is not fully known, assays using different biological systems need to be performed. Red blood cells (RBC) are labeled with technetium-99m (Tc-99m) and used in nuclear medicine. The labeling depends on a reducing agent, usually stannous chloride $\left(\mathrm{SnCl}_{2}\right)$. We assessed the effect of different concentrations of EGb on the labeling of blood constituents with Tc-99m, as sodium pertechnetate (3.7 MBq), and on the mobility of a plasmid DNA treated with $\mathrm{SnCl}_{2}(1.2 \mu \mathrm{g} / \mathrm{ml})$ at room temperature. Blood was incubated with $\mathrm{EGb}$ before the addition of $\mathrm{SnCl}_{2}$ and Tc-99m. Plasma (P) and $\mathrm{RBC}$ were separated and precipitated with trichloroacetic acid, and soluble (SF-P and SF-RBC) and insoluble (IF-P and IF-RBC) fractions were isolated. The plasmid was incubated with $\mathrm{Egb}, \mathrm{SnCl}_{2}$ or $\mathrm{EGb}$ plus $\mathrm{SnCl}_{2}$ and agarose gel electrophoresis was performed. The gel was stained with ethidium bromide and the DNA bands were visualized by fluorescence in an ultraviolet transilluminator system. EGb decreased the labeling of RBC, IF-P and IF-RBC. The supercoiled form of the plasmid was modified by treatment with $\mathrm{SnCl}_{2}$ and protected by 40 $\mathrm{mg} / \mathrm{ml} \mathrm{EGb}$. The effect of EGb on the tested systems may be due to its chelating action with the stannous ions and/or pertechnetate or to the capability to generate reactive oxygen species that could oxidize the stannous ion.
\end{abstract}

Ginkgo biloba extract (EGb 761) is a commercial and standardized mixture of active substances which include flavonoid glycosides (24\%) and terpenoids (6\%) obtained from the green leaves of the G. biloba tree
Key words

- Ginkgo biloba extract

- Blood element labeling

- Technetium-99m

- Stannous chloride

- Plasmid DNA
(1). The majority of research on the therapeutic effects of ginkgo has been done using this standardized G. biloba leaf extract called EGb 761, which is a registered drug in Germany. EGb 761 is concentrated approxi- 
mately $50: 1 \mathrm{w} / \mathrm{w}(50 \mathrm{~kg}$ of leaves to make 1 $\mathrm{kg}$ of EGb 761). The extract scavenges free radicals such as hydroxyl radicals and superoxide anions (1-3). The redox properties of this extract are probably due to the presence of the flavonoids (1-3). They react with hydroxyl radicals and yield an additional product which scavenges hydroxyl radicals $(2,4)$.

Radiopharmaceutical agents labeled with technetium-99m (Tc-99m) are widely used in nuclear medicine as imaging agents (5). The physical, chemical and biological characteristics of Tc-99m, in addition to its low cost and easy availability, justify its widespread use (5,6). Red blood cells (RBC) and plasma proteins are usually labeled with Tc$99 \mathrm{~m}$ to be used as radiopharmaceuticals (512). The labeling technique is based on the reducing ability of stannous salts when blood samples are incubated with these ions and then exposed to Tc-99m, as sodium pertechnetate (5-8).

Stannous chloride $\left(\mathrm{SnCl}_{2}\right)$ is known i) to inhibit the immune response in rodents, ii) to alter gene expression, and iii) to induce tumor generation in the thyroid gland. There is no general agreement regarding its genotoxicity and it has been suggested that the effects of this salt depend on the physicochemical conditions and the route of its administration. This salt is administered directly intravenously to human beings when it is used as a reducing agent to prepare Tc$99 \mathrm{~m}$ radiopharmaceuticals (12). Studies have revealed that $\mathrm{SnCl}_{2}$ can generate ROS and breaks in plasmid DNA (12-17). $\mathrm{SnCl}_{2}$ is capable of inducing the generation of ROS that are responsible for oxidative stress (1215).

Various factors that can influence the labeling and biodistribution of radiopharmaceuticals have been reported. Some important interfering factors are the radiolabeling method used, the stannous ion concentration, the presence of some diseases, and/or the presence of drugs in patient plasma (7). Some investigators have reported that phy- totherapeutic agents may alter the labeling of blood elements with Tc-99m (7-12).

The objective of the present study was to determine the effect of a G. biloba extract on the labeling of RBC and plasma proteins with Tc-99m in vitro and to assess the possible interference of this phytotherapeutic agent with the integrity of a plasmid DNA submitted to treatment with $\mathrm{SnCl}_{2}$.

A solution of a commercial G. biloba extract (Farmacutis, Rio de Janeiro, RJ, Brazil/Jiangsu Medicines and Health Products, lot No. GB 001128, Jiangsu, China) standardized to contain $24 \%(\mathrm{w} / \mathrm{v})$ flavonoids was prepared in $0.9 \% \mathrm{NaCl}$. Dilutions in $0.9 \% \mathrm{NaCl}(\mathrm{w} / \mathrm{w})$ containing $0.004,0.04$, $0.4,4.0,20$ and $40 \mathrm{mg} / \mathrm{ml}$ of the commercial extract were prepared. Blood $(0.5 \mathrm{ml})$ with anticoagulant (heparin) obtained from female Wistar rats was incubated for $60 \mathrm{~min}$ under gentle mixing with $100 \mu \mathrm{l}$ of the different G. biloba dilutions, $0.5 \mathrm{ml}$ of freshly prepared $\mathrm{SnCl}_{2}(1.2 \mu \mathrm{g} / \mathrm{ml}$; Sigma, St. Louis, MO, USA) was added under vacuum and the incubation was continued for an additional $60 \mathrm{~min}$. Tc-99m (sodium pertechnetate, 100 $\mu 1,3.7 \mathrm{MBq} / \mathrm{ml}$ ) recently obtained from a molibdenium-99/Technetium-99m generator (Instituto de Pesquisas Energéticas e Nucleares, Comissão Nacional de Energia Nuclear, São Paulo, SP, Brazil) was added and incubation was continued for another $10 \mathrm{~min}$. These mixtures were centrifuged for $5 \mathrm{~min}$ and plasma and RBC were separated. Plasma samples (P) and RBC aliquots $(20 \mu \mathrm{l})$ were also precipitated with $1 \mathrm{ml} 5 \%(\mathrm{w} / \mathrm{v})$ trichloroacetic acid and soluble (SF) and insoluble fractions (IF) were separated by centrifugation. The radioactivity of plasma, $\mathrm{RBC}$, IF$\mathrm{P}, \mathrm{SF}-\mathrm{P}, \mathrm{IF}-\mathrm{RBC}$ and SF-RBC was determined with a well counter (Clinigamma, gamma counter, LKB, Wallac, Finland) and percent recovered radioactivity ( $\%$ ATI $)$ was reported (8-12).

Data were analyzed statistically by ANOVA and by the Tukey-Kramer and Dunnett tests, with the level of significance 
set at $\mathrm{P}<0.005$.

Plasmid DNA (pUC 9.1) was obtained by the alkaline lysis method as described by Sambrook et al. (18). Plasmids were separated from high molecular weight RNA contaminants by $\mathrm{LiCl}$ precipitation $(2.5 \mathrm{M}$ final concentration), while the residual RNA contaminants were digested by RNAse $(20 \mu \mathrm{g} /$ $\mathrm{ml}$ ) treatment for $30 \mathrm{~min}$ at room temperature.

Plasmid dispersions were diluted, added to Eppendorf tubes (200 ng per tube) and incubated with $200 \mu \mathrm{g} / \mathrm{ml} \mathrm{SnCl}_{2}$ in $10 \mathrm{mM}$ Tris- $\mathrm{HCl}$ buffer, $\mathrm{pH}$ 7.4. To determine if EGb caused DNA damage, 0.4, 4, 20 and 40 $\mathrm{mg} / \mathrm{ml}$ were added to the DNA preparation. To investigate the influence of EGb on DNA breaks induced by $\mathrm{SnCl}_{2}$, the extract $(40 \mathrm{mg}$ / $\mathrm{ml}$ ) was added to the DNA preparation before treatment with the reducing agent. In all cases, the reaction was carried out at $37^{\circ} \mathrm{C}$ for $40 \mathrm{~min}$. The formation of single strand breaks (SSB) was determined by $0.8 \%$ agarose gel electrophoresis in order to separate the different conformations of plasmid DNA, i.e., form I, supercoiled native conformation, and form II, open circle resulting from SSB. Aliquots of each sample $(10 \mu \mathrm{l})$ were mixed with $2 \mu 1$ of $6 \mathrm{X}$ concentrated electro- phoresis loading buffer $(0.25 \%$ xylene cyanol FF, $0.25 \%$ bromophenol blue, $30 \%$ glycerol), and applied to a horizontal gel in Tris acetate-EDTA buffer, pH 8.0. After electrophoresis, the gel was stained with ethidium bromide $(0.5 \mu \mathrm{g} / \mathrm{ml})$ and the DNA bands were visualized by fluorescence in an ultraviolet transilluminator system. Permanent records were obtained with a Polaroid MP$4^{+}$camera.

The distribution of radioactivity in plasma and $\mathrm{RBC}$ from whole blood treated with different concentrations of $G$. biloba extract (crude extract) is presented in Table 1. There was a significant decrease $(\mathrm{P}<0.05)$ in Tc$99 \mathrm{~m}$ binding and uptake by $\mathrm{RBC}$ in the presence of G. biloba concentrations above $20 \mathrm{mg} / \mathrm{ml}$ was observed. Binding of radionuclide to the IF and SF of plasma and IF and $\mathrm{SF}$ of red cells obtained from the same blood was also significantly decreased $(\mathrm{P}<0.05)$ when G. biloba extract concentrations of 20 and $40 \mathrm{mg} / \mathrm{ml}$ were tested.

The results illustrated in Figure 1 indicate that the EGb did not induce DNA changes (lanes 3, 4, 5 and 6). The sample reaction with $\mathrm{SnCl}_{2}$ (positive control) induced breaks in plasmid DNA (lane 8). Nevertheless, when the plasmid was incubated

\begin{tabular}{|c|c|c|c|c|c|c|}
\hline \multirow[t]{2}{*}{$\mathrm{EGb}(\mathrm{mg} / \mathrm{ml})$} & \multicolumn{6}{|c|}{ Radioactivity (\%) } \\
\hline & Red blood cells & Plasma & IF-P & SF-P & IF-RBC & SF-RBC \\
\hline 0.0 (control) & $97.2 \pm 1.9$ & $2.8 \pm 1.9$ & $80.7 \pm 2.9$ & $19.2 \pm 2.9$ & $86.6 \pm 5.0$ & $13.3 \pm 5.0$ \\
\hline 0.004 & $95.5 \pm 3.7$ & $4.4 \pm 3.7$ & $80.5 \pm 2.7$ & $19.4 \pm 2.7$ & $88.7 \pm 4.5$ & $10.9 \pm 4.5$ \\
\hline 0.04 & $98.2 \pm 0.3$ & $1.7 \pm 0.3$ & $78.0 \pm 3.5$ & $21.9 \pm 3.5$ & $89.2 \pm 1.0$ & $10.7 \pm 1.0$ \\
\hline 0.4 & $97.0 \pm 1.1$ & $2.9 \pm 1.1$ & $86.7 \pm 1.5$ & $13.2 \pm 1.5$ & $90.8 \pm 1.8$ & $9.1 \pm 1.8$ \\
\hline 4.0 & $93.8 \pm 3.4$ & $6.1 \pm 3.4$ & $81.6 \pm 7.5$ & $18.3 \pm 7.5$ & $90.1 \pm 5.0$ & $9.9 \pm 5.0$ \\
\hline 20.0 & $71.0 \pm 7.5^{*}$ & $28.9 \pm 7.5$ & $20.9 \pm 7.3^{*}$ & $79.4 \pm 7.3$ & $83.1 \pm 6.0^{*}$ & $16.9 \pm 6.0$ \\
\hline 40.0 & $64.9 \pm 6.5^{*}$ & $35.0 \pm 6.5$ & $20.2 \pm 2.2^{*}$ & $79.8 \pm 2.2$ & $75.5 \pm 9.0^{*}$ & $24.4 \pm 9.0$ \\
\hline
\end{tabular}

Heparinized blood was incubated with Ginkgo biloba crude extract (EGb). Stannous chloride, $1.2 \mu \mathrm{g} / \mathrm{ml}$, was present in all samples. The radioactivity incorporated into each fraction is reported as percent recovered in IFP plus SF-P, IF-RBC plus SF-RBC and RBC plus plasma. IF-P = insoluble plasma fraction; IF-RBC = insoluble red blood cell fraction; $\mathrm{SF}-\mathrm{P}=$ soluble plasma fraction; $\mathrm{SF}-\mathrm{RBC}=$ soluble red blood cell fraction. ${ }^{*} \mathrm{P}<0.05$ compared to control (ANOVA, $\mathrm{N}=6$ per group). 
with $\mathrm{SnCl}_{2}$ and with EGb $(40 \mathrm{mg} / \mathrm{ml})$, protection of DNA was observed (lane 7) at 20 $\mathrm{mg} / \mathrm{ml}$ but not at $4 \mathrm{mg} / \mathrm{ml} \mathrm{EGb}$.

Evidence that medicinal plant products can affect radiolabeling of RBC in the context of clinical nuclear medicine has come to light only recently, and a number of researchers have turned their attention to in vitro testing of the drug with labeled RBC $(6,7)$. Some studies on the effect of natural products (Thuya occidentalis, Nicotiana tabacum, Paullinia cupana, Brassica oleracea L. var. botrytis, Fucus vesiculosus) on RBC labeling have shown that this action could be due to the redox properties of the extract (T. occidentalis, $N$. tabacum, $P$. cupana, B. oleracea L. var. botrytis, $F$.

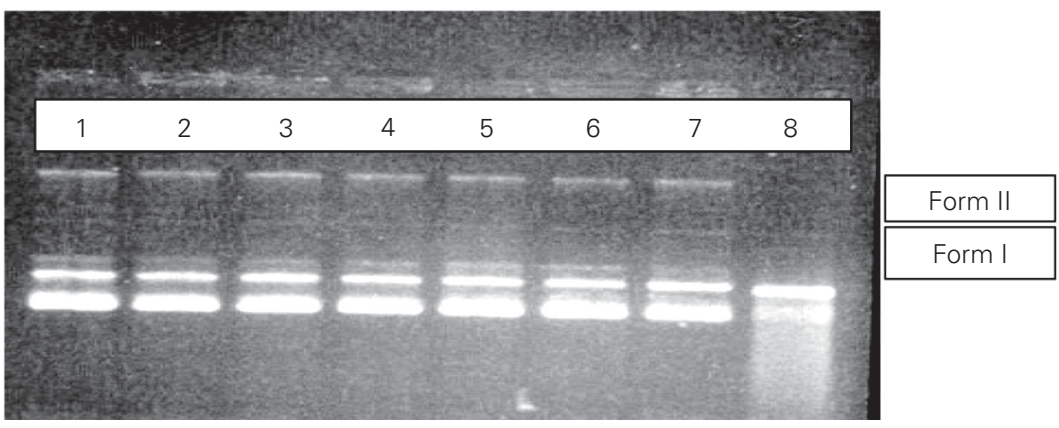

Figure 1. Ginkgo biloba crude extract (EGb) protects pUC 9.1 plasmid DNA from degradation by $\mathrm{SnCl}_{2}$. After incubation at pH 7.4, plasmid plus EGb (lanes 3-6) or plasmid plus EGb plus $200 \mu \mathrm{g} / \mathrm{ml} \mathrm{SnCl}_{2}$ (lane 7) were submitted to agarose gel electrophoresis. Lane $1=\mathrm{H}_{2} \mathrm{O}$ control containing plasmid, Lane 2 = saline control containing plasmid. The amount of EGb was $0.4 \mathrm{mg} / \mathrm{ml}$ (lane 3), $4.0 \mathrm{mg} / \mathrm{ml}$ (Lane 4), $20 \mathrm{mg} / \mathrm{ml}$ (lane 5), $40 \mathrm{mg} / \mathrm{ml}$ (lane 6), and 200 $\mu \mathrm{g} / \mathrm{ml} \mathrm{SnCl}_{2}$ (lane 8). I = supercoiled form; II = open circle form. vesiculosus) (8-12).

The present results indicate that the labeling of blood elements with Tc-99m depends on EGb concentration. Although some investigators have reported the anti-oxidant properties (1-3) of EGb, our results indicate that this extract may also have oxidant activity. Probably, the stannous ion would be oxidized to stannic ion that is not capable to reduce the pertechnetate ion, decreasing the fixation of the Tc-99m on its binding sites.

We also suggest that the DNA protection induced by EGb (Figure 1) could be explained by the presence of hydroxyl groups in the flavonoid fraction which react with stannous ions, thereby preventing free radical generation and protecting the cells against $\mathrm{SnCl}_{2}$ oxidation.

The present results confirm that $\mathrm{SnCl}_{2}$ damages DNA. This effect may be related to the generation of ROS. The results in Figure 1 show that up to $40 \mathrm{mg} / \mathrm{ml} \mathrm{EGb}$ has no damaging effect on plasmid DNA and also show the protective effect (lane 7) of $40 \mathrm{mg} /$ $\mathrm{ml}$ EGb against the damaging action of 200 $\mu \mathrm{g} / \mathrm{ml} \mathrm{SnCl}_{2}$ on plasmid DNA (lane 8). Both the action of EGb on the labeling of blood constituents and its protection of DNA against the effect of $\mathrm{SnCl}_{2}$ may be related to chelation of the stannous and pertechnetate ions or to the possible generation of ROS that may oxidize the stannous ion.

\section{References}

1. Bastianetto S, Zheng W \& Quirion R (2000). The Ginkgo biloba extract (EGb761) protects and rescues hippocampal cells against nitric oxide-induced toxicity: involvement of its flavonoid constituents and protein kinase C. Journal of Neurochemistry, 74: 22682276.

2. Yucheng N, Baolu Z, Jingwu H \& Wenjuan X (1996). Preventive effect of Ginkgo biloba extract on apoptosis in rat cerebellar neuronal cells induced by hydroxyl radicals. Neuroscience Letters, 214: 115-118.

3. Diamond BJ, Shiflet SC, Fewel N, Matheis RJ, Noskin O \& Richards JA (2000). Ginkgo biloba extract: Mechanisms and clinical indications. Archives of Physical Medicine and Rehabilitation, 81: 668678.
4. Pietta PG (2000). Flavonoids as antioxidants. Journal of Natural Products, 63: 1035-1042.

5. Early PJ \& Sodee DB (1995). Principles and Practice of Nuclear Medicine. Mosby YearBook, St. Louis, MO, Toronto, Canada, 94110.

6. Harbert JC (1996). Nuclear Medicine. Diagnosis and Therapy. Thieme Medical Publishers, New York, 190-201.

7. Sampson CB (1996). Complications and difficulties in radiolabeling blood cells: A review. Nuclear Medicine Communications, 17: 648658.

8. Vidal MV, Gutfilen B, Fonseca LMB \& Bernardo-Filho M (1998) Influence of tobacco on labeling of red blood cells and plasma proteins with technetium-99m. Journal of Experimental and Clinical 
Cancer Research, 17: 1-6.

9. Oliveira JF, Oliveira MB, Ávila AS, Braga ACS, Catanho MTJA, Jales RLC, Cardoso VN \& Bernardo-Filho M (2003). Assessment of the effect of Fucus vesiculosus extract on the labeling of blood constituents with technetium-99m and the histological modifications on the shape of the red blood cells. Food and Chemical Toxicology, 41: $15-20$

10. Oliveira JF, Braga ACC, Ávila AS, Fonseca LMB, Gutfilen B \& Bernardo-Filho M (1997). Effect of Thuya occidentalis on the labeling of red blood cells and plasma proteins with technetium-99m. Yale Journal of Biology and Medicine, 69: 489-494.

11. Lima EAC, Diré G, Mattos DMM, Freitas RS, Gomes MBN, Faria MVC, Jales RL \& Bernardo-Filho M (2002). Effect of an extract of cauliflower (leaf) on the labeling of blood elements with technetium$99 \mathrm{~m}$ and on the survival of Escherichia coli AB1157 submitted to the treatment with stannous chloride. Food and Chemical Toxicology, 40: 919-923.

12. Oliveira JF, Braga ACS, Oliveira MBN, Boasquevisque EM, Jales RL, Cardoso VN \& Bernardo-Filho M (2002). Effect of extract of medicinal plants on the labeling of blood elements with technetium$99 \mathrm{~m}$ and on the morphology of red blood cells: I-a study with Paullinia cupana. Fitoterapia, 73: 305-312.
13. Bernardo-Filho M, Gutfilen B \& Maciel OS (1994). Effect of different anticoagulants on the labeling of red blood cells and plasma proteins with technetium-99m. Nuclear Medicine Communications, 15: 730-734.

14. Billinghurst MW \& Jette D (1980). In vitro kinetics of red blood cell labeling with Tc-99m in association with stannous pyrophosphate. Journal of Radiological Chemistry, 59: 579-584.

15. Caldeira-de Araújo A, Dantas FJS, Moraes MO, Felzenszwalb I \& Bernardo-Filho M (1996). Stannous chloride participates in the generation of reactive oxygen species. Journal of the Brazilian Association for the Advancement of Science, 48: 109-113.

16. Dantas FJS, Moraes MO, De Mattos JCP, Bezerra RJAC, Carvalho EF, Bernardo-Filho M \& Caldeira-de-Araújo A (1999). Stannous chloride mediates single strand breaks in plasmid DNA through reactive oxygen formation. Toxicology Letters, 110: 129-136.

17. Reiniger IW, Silva CR, Felzenszwalb I, Mattos JCP, Oliveira JF, Dantas FJS, Bezzerra RJAC, Caldeira-de Araújo A \& Bernardo-Filho $M$ (1999). Boldine action against the stannous chloride effect. Journal of Ethnopharmacology, 68: 345-348.

18. Sambrook J, Fritsch EF \& Maniatis T (1989). Extraction and purification of plasmid DNA. In: Molecular Cloning. A Laboratory Manual. Cold Spring Harbor Laboratory, Cold Spring Harbor, NY. 